準近居の存在からみた老親世帯の自立と支援を止揚するサポート居住の動向 親子の居住関係を軸とする高齢者のサポート構造に関する研究 その 1

\title{
INTEGRATION INDEPENDENCE OF THE AGED PARENTS WITH SUPPORT BY THEIR CHILDREN FAMILY ON THE SEMI-CLOSE RESIDENTIAL RELATIONSHIP
}

Study on the support structure for the aged parents by family ties Part 1

\author{
上和田 茂*，鳥飼 香代子**，山田 英 代***，付 開 楠**** \\ Shigeru KAMIWADA, Kayoko TORIKAI, Hideyo YAMADA \\ and Kainan $F U$
}

\begin{abstract}
The aim of this study is to consider the trend of the support for the aged parents based on the residential relationship between parents and children. On this paper, we made clear as follows. The lodging household which the aged parents reside with children family is decreasing recently. Instead of the lodging household, Semi-close residential rerationship is increasing. Semi-close residential rerationship mean that children family take up their residence at halfway between their work place and parents house to keep a balance between support the aged parents and convenience of commuter trip. There are mutch contact and support for parents by children family in the semi-close residentiali relationship.
\end{abstract}

Keywords : Residence to support, Independence, Support, Lodging Household, Semi-Close Residential Relationship サポート居住，親子の居住関倸，自立，支援，同居，準近居

1. はじめに

\section{1 研究の目的}

親子両世帯が距離的に離れて居住していながら、他方、日常的に 密な接触、交流、協力、支援といった行為を通して互いに支え合う 家族関係およびその居住関係を、これまでは、「修正拡大家族」「親 密別居」「ネットワーク居住」などと様々に称されてきた。1)2３）

本研究は、このような家族居住関係に注目すると共に、それらを 高齢者支援の視点から「サポート居住」と再認識し、その動向につ いて、中部、近畿、中国、四国、九州の 5 地方の実態をとおして考 察するものである。

親子両世帯の居住関係の統計については、国調がそうであるよう に、これまでは「同居」と「同居以外」の区別がつく程度のデータ しか存在せず、家族を軸とする高齢者の支援の方策を構想すること に制約があった。本研究では、同居以外の家族居住関係をきめ細かく 捉え、高齢者のサポートネットワーク構築の一助としたい。

\section{2 離れていても親しい関係}

既往研究等によると、生活の近代化および個人化の傾向が強まる のに伴い、生活上の軒轁を避けるため親子両世帯には斥力が働く一 方、家族共同体意識も完全に払拭されるわけでもなく、したがって 両世帯間にある種の引力も今なお存在するとの見方が大勢を占める。
特に、親が高齢化するほどその絆は強化され、と同時に、公的な支援 や介護あるいは市場メカニズムによるサービスでは得られ難い柔軟 で情緒的なサポートの需要はますます増大しており、かかつてのよう な「同居」によるサポートは減少したものの、つかず離れずの関係 で支援が可能な居住関係は増加の傾向、少なくとも意識の上ではそ の方向にあることが報じられている。4)

たとえば、総理府が 1994 年に 30 歳以上 60 歳未満の人を対象とし て実施した意識調査でも、「離れて生活するが、親子としてのきずな は保つようにする」との回答が $41.4 \%$ と群を抜いて多くみられ、こ のような親子関倸の持続への強い指向がうかがわれる。 ${ }^{5)}$

こういった傾向から、現在あるいは将来において望まれる親子の 居住関係の輪郭として、「形態としての同居は避けながら、相互の情 緒的関係は限りなく同居に近いものを維持する小、そういった居住関 係が浮かび上がってくるであろう。社会学者の直井道子氏は、これ を「離れていても親しい関係」と称しているが、今後、高齢化と共 に少子化が進み、親子の絆が緊密になると、これらの傾向はますま す強まることが予想される。6)

\section{3 自立と支援を止揚するサポート居住}

ところで一方、上記のような傾向は、やむを得ず「離れて住まわ ざるを得ない」が「親しい関倸は保ちたい」という消極的姿勢を示
* 九州産業大学工学部建築学科 教授 $\cdot$ 工博

** 能本大学教育学部家政学専修 教授 · 学博

*** 石川工業高等尃門学校建築学科 助教授. 工博

**** 九州産業大学大学院工学研究科博士後期課程 大学院生・工修
Prof., Dept of Architecture, Faculty of Engineering, Kyushu Sangyo Univ., Dr. Eng. Prof., Faculty of Education, Kumamoto Univ., Ph. D.

Assoc. Prof., Dept. of Architecture, Ishikawa National College of Technology, Dr. Eng.

Graduate Student, Graduate School of Engineering, Kyushu Sangyo Univ., M. Eng. 
すものにとどまらない。近年、年金等により高齢者の経済的環境は 向上し、また身体的ケア環境も改善される傾向にある。それらを背 景として高齢者の自立も急速に進み、それぞれの高龄者が、その置 かれた環境条件や生活条件のもとで自らの生活を自らがデザインし、 そして自らが選好するライフスタイルを貫こうとする指向も強まっ ている。参考文献 11)12)

したがって、「子どもと離れて住む」ことは必ずしも仕方なく選択 されるわけではなく、むしろ積極的に選択されるものともなってい る。また同様の理由から、たとえ同居や隣居などでも、必要以上に 依存することは避け、互いに自立した関係を保つ、すなわち「近く にいても自立した関倸」も強まる傾向が認められる。このように解 釈できるならば、同居から遠居までの親子の居住関係の幅は、子ど もの側の就業問題等を基本要因としつつも、極論すれば老親の自立 度と依存度とのバランスに帰着するといってもよい。多文献 1112)

1.4 準近居について

本研究は、実態調査を通してこれらの諸点を考察する手がかりを 得ることを目的とするが、上記のような高齢者の自立と依存・支援 の関保を明確に把握する手段として「準近居」なる存在に注目した。

「準近居」とは、子世帯が親元と自らの就業地との中間地に居住 し、通勤等の利便性と親世帯への目配りや接触の容易性とのバラン スを図ろうとする居住形態と定義する。両者の中間に位置する自治 体に居住するケースが最もわかりやすい事例であるが、距離的バラ ンスの点から、結果的に、親元あるいは就業地のいずれかが属する 自治体内に居住する場合であっても「準近居」と抎大解积しても差 し支えないと思われる。また、頻繁に親元に帰省し、親の生活を物 理的あるいは精神的に支援することが可能な圈域に居住するといつ た意味から、「準近居」を「様子見圏居住」と言い換えることも可能 であろう。

本稿においては、「同居」「隣居」「近居」「遠居」といった既成の 親子居住関係の分類に加えて、「近居」と「遠居」の中間形態である 「準近居」を措定し、この実態に焦点をあてたい。

\section{5 論文の檴成}

本編では、サポート居住類型別の発生分布、特に「淮近居」の発 生実態について報告をおこない、次編において、子世帯による親世 帯への支援および近隣を含めたサポートネットワークの現状につい て報告をおこなう。なお、本編での報告は、サポート居住の概略の 動向を把握することを目的とした「各市町村の住民課長向け調査小、 および高踰者自身を対象としてサポート居住の詳細を把握すること を目的とした「民生委員による調査」の 2 つ調査結果に基づく。

\section{2. サポート居住における概略の動向}

\section{2-1 調查概要}

サポート居住の動向について、その概略を把握するために、中部 地方以西の全県における全市町村 2,124 箇所の住民課長（または関 係課長) を対象として郵送アンケートを実施した。調査は 3 回に分 けておこなった。第 1 次は平成 9 年 7 月〜 8 月、第 2 次は平成 10 年 8 月、第 3 次は平成 13 年 2 月〜 3 月である。各県別の配布数および有 効回答率は表 1 に示すとおりである。

なお、回答は裏付けとなる資料に基づくものではなく、業務を通 ごて住民課長が認識している範囲のものを求めた。データとしては
表1 調㴅概要(住民課長向け調疽)

\begin{tabular}{|c|c|c|c|c|}
\hline 地方名 & 都道府県名 & 配布数 & 有効回答 & 有効回答率 (\%) \\
\hline \multirow[t]{2}{*}{ 中部地方 } & 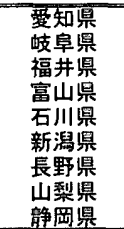 & $\begin{array}{c}88 \\
99 \\
35 \\
35 \\
41 \\
112 \\
121 \\
64 \\
75\end{array}$ & $\begin{array}{l}55 \\
59 \\
15 \\
17 \\
19 \\
75 \\
61 \\
29 \\
43\end{array}$ & $\begin{array}{l}62.5 \\
59.6 \\
42.9 \\
48.6 \\
46.3 \\
67.0 \\
50.4 \\
45.3 \\
57.3 \\
\end{array}$ \\
\hline & 小計 & 670 & 373 & 55.7 \\
\hline \multirow[t]{2}{*}{ 近䋐地方 } & $\begin{array}{c}\text { 太阪府 } \\
\text { 京都府 } \\
\text { 兵廂県 } \\
\text { 滋贺県 } \\
\text { 奈良県 } \\
\text { 和歌山県 } \\
\text { 三重県 }\end{array}$ & $\begin{array}{l}44 \\
44 \\
88 \\
50 \\
47 \\
50 \\
69 \\
\end{array}$ & $\begin{array}{l}14 \\
22 \\
32 \\
17 \\
18 \\
29 \\
37 \\
\end{array}$ & $\begin{array}{l}31.8 \\
50.0 \\
36.4 \\
34.0 \\
38.3 \\
58.0 \\
53.6 \\
\end{array}$ \\
\hline & 小計 & 392 & 169 & 43.1 \\
\hline \multirow[t]{2}{*}{ 中国地方 } & $\begin{array}{l}\text { 岡山県 } \\
\text { 鳥取県 } \\
\text { 庢島県 } \\
\text { 島根県 } \\
\text { 山口県 }\end{array}$ & $\begin{array}{l}78 \\
39 \\
94 \\
59 \\
56 \\
\end{array}$ & $\begin{array}{l}55 \\
23 \\
56 \\
45 \\
39 \\
\end{array}$ & $\begin{array}{l}70.5 \\
59.0 \\
59.6 \\
76.3 \\
69.6 \\
\end{array}$ \\
\hline & 小計 & 326 & 218 & 66.9 \\
\hline \multirow[t]{2}{*}{ 四国地方 } & $\begin{array}{l}\text { 德島 } \\
\text { 香川県 } \\
\text { 高知県 } \\
\text { 愛媛県 }\end{array}$ & $\begin{array}{l}50 \\
43 \\
53 \\
70 \\
\end{array}$ & $\begin{array}{l}28 \\
30 \\
31 \\
41 \\
\end{array}$ & $\begin{array}{l}56.0 \\
69.8 \\
58.5 \\
58.6 \\
\end{array}$ \\
\hline & 小 計 & 216 & 130 & 60.2 \\
\hline \multirow[t]{2}{*}{ 九州地方 } & 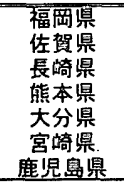 & $\begin{array}{l}97 \\
49 \\
79 \\
98 \\
58 \\
44 \\
95 \\
\end{array}$ & $\begin{array}{l}50 \\
29 \\
35 \\
72 \\
33 \\
29 \\
53 \\
\end{array}$ & $\begin{array}{l}51.5 \\
59.2 \\
44.3 \\
73.5 \\
56.9 \\
65.9 \\
55.8 \\
\end{array}$ \\
\hline & 小 計 & 520 & 301 & 57.9 \\
\hline \multicolumn{2}{|c|}{ 合計 } & 2124 & 1191 & 56.1 \\
\hline
\end{tabular}

泰2 同居以外のサポート居住の增加傾向

\begin{tabular}{|c|c|c|c|c|c|c|c|c|c|c|c|c|c|}
\hline 地方 & 都道府喿名 & & य< & ある & 程度 & 兆仿 & 案有り & 兆倾 & 無し & もと & から & 合 & 計 \\
\hline \multirow{10}{*}{$\begin{array}{l}\text { 中 } \\
\text { 部 } \\
\text { 地 } \\
\text { 方 }\end{array}$} & 愛知県 & & $14.5 x$ & & 49.18 & & 27.38 & & & 2 & $3.6 \%$ & $55 !$ & $100.0 x$ \\
\hline & 攱阜県 & 16 & 27.18 & 29 & $49.2 x$ & 9 & $15.3 x$ & 4 & 6.88 & 7 & 1.78 & 59 & $100.0 \%$ \\
\hline & 福井県 & 4 & $26.7 x$ & 8 & $53.3 x$ & 3 & 20.06 & 0 & $0.0 \%$ & 0 & 0.08 & 15 & $100.0 \%$ \\
\hline & 富山県 & 2 & $11.8 x$ & 6 & $35.3 \%$ & 6 & $35.3 \%$ & 3 & $17.6 \%$ & 0 & 0.08 & 17 & $100.0 x$ \\
\hline & 石川県 & 3 & $15.8 \%$ & 7 & $36.8 \mathrm{x}$ & 8 & $42.1 x$ & 1 & $5.3 \%$ & 0 & 0.08 & 19 & $100.0 \%$ \\
\hline & 新潟県 & 15 & $20.0 x$ & 28 & 37.38 & 25 & $33.3 x$ & 7 & $9.3 x$ & 0 & $0.0 \%$ & 75 & $100.0 x$ \\
\hline & 長野県 & 13 & $21.3 \mathrm{x}$ & 31 & $50.8 \mathrm{x}$ & 14 & $23.0 \%$ & 3 & 4.98 & 0 & $0.0 \%$ & 61 & $100.0 \%$ \\
\hline & 山梨県 & 11 & $37.9 \%$ & 13 & $44.8 \%$ & 4 & $13.8 \%$ & 0 & $0.0 \%$ & 1 & 3.48 & 29 & $100.0 \%$ \\
\hline & 觧岡県 & 10 & $23.3 \%$ & 19 & $44.2 \%$ & 11 & $25.6 \%$ & 2 & 4.78 & 1 & $2.3 x$ & 43 & $100.0 \%$ \\
\hline & 小 計 & 82 & $22.0 \%$ & 168 & $45.0 \%$ & 95 & $25.5 \%$ & 23 & $6.2 \%$ & 5 & 1.36 & 373 & $100.0 \%$ \\
\hline \multirow{8}{*}{$\begin{array}{l}\text { 近 } \\
\text { 地 } \\
\text { 方 }\end{array}$} & 大阪府 & 2 & $14.3 \%$ & 10 & $71.4 x$ & 2 & $14.3 \mathrm{x}$ & 0 & $0.0 \%$ & 0 & $0.0 \%$ & 14. & $100.0 \%$ \\
\hline & 京都府 & 6 & 27.38 & 14 & $63.6 \%$ & 1 & $4.5 \%$ & 0 & $0.0 \%$ & 1 & 4.58 & 22 & $100.0 \%$ \\
\hline & 兵庫県 & 8 & 25.08 & 16 & $50.0 \mathrm{x}$ & 5 & $15.6 \%$ & 3 & $9.4 x$ & 0 & 0.08 & 32. & $100.0 \%$ \\
\hline & 滋賀県 & 1 & $5.9 \%$ & 11 & 64.78 & 4 & $23.5 x$ & 0 & $0.0 \%$ & 1 & $5.9 \%$ & 17) & $100.0 \%$ \\
\hline & 奈良県 & 2 & $11.1 \mathrm{x}$ & 10 & $55.6 \mathrm{x}$ & 5 & $27.8 x$ & 1 & $5.6 \%$ & 0 & 0.08 & 18 & $100.0 \%$ \\
\hline & 和歌山県 & 13 & $44.8 \%$ & 13 & $44.8 \%$ & 3 & 10.38 & 0 & $0.0 \%$ & 0 & $0.0 \%$ & 29 & $100.0 \%$ \\
\hline & 三重罧 & 11 & 29.78 & 19 & $51.4 x$ & 7 & $18.9 x$ & 0 & $0.0 \%$ & 0 & $0.0 \%$ & 37. & $100.0 \%$ \\
\hline & 小訪 & 43 & $25.4 \mathrm{X}$ & 93 & $55.0 \%$ & 27 & $\mid 16.0 \%$ & 4 & $2.4 x$ & 2 & $1.2 x$ & 169 & $100.0 \%$ \\
\hline \multirow{6}{*}{$\begin{array}{l}\text { 中 } \\
\text { 国 } \\
\text { 地 } \\
\text { 方 }\end{array}$} & 岡山県 & 8 & $14.5 \%$ & 32 & 58.28 & 11 & $20.0 \%$ & 3 & $5.5 x$ & 1 & 1.88 & 55 & $100.0 \%$ \\
\hline & 鳥取県 & 4 & $17.4 \%$ & 10 & 43.58 & 7 & $30.4 \%$ & 2 & 8.78 & 0 & $0.0 \%$ & 23 & $100.0 \%$ \\
\hline & 広島県 & 15 & $26.8 x$ & 27 & $48.2 x$ & 11 & $19.6 \%$ & 2 & $3.6 \%$ & 1 & $1.8 x$ & 56 & $100.0 \%$ \\
\hline & 島根県 & 8 & $17.8 \%$ & 29 & $64.4 \gamma$ & 6 & $13.3 \%$ & 1 & $2.2 \%$ & 1 & $2.2 x$ & 45 & $100.0 \%$ \\
\hline & 山口県 & 12 & $30.8 \%$ & 19 & $48.7 x$ & 4 & $10.3 \%$ & 4 & 10.38 & 0 & $0.0 *$ & 39 & $100.0 \%$ \\
\hline & 小 尌 & 47 & $21.6 \%$ & 117 & $53.7 \%$ & 39 & $\mid 17.9 x$ & 12 & $5.5 \%$ & 3 & $1.4 \%$ & 218 & $100.0 x$ \\
\hline \multirow{5}{*}{$\begin{array}{l}\text { 四 } \\
\text { 国 } \\
\text { 地 } \\
\text { 方 }\end{array}$} & 德島県 & 12 & $42.9 x$ & 9 & 32.18 & 5 & 17.98 & 0 & $0.0 *$ & 2 & 7.18 & 28 & 100.08 \\
\hline & 香川県 & 6 & $20.0 \%$ & 18 & $60.0 \%$ & $\overline{6}$ & $20.0 \%$ & 0 & 0.08 & 0 & $0.0 x$ & 30 & $100.0 \%$ \\
\hline & 高知県 & 15 & $48.4 \mathrm{x}$ & 8 & 25.88 & 5 & $16.1 x$ & 2 & 6.58 & 1 & 3.28 & 31 & $100.0 \%$ \\
\hline & 愛授県 & 15 & 36.68 & 16 & $39.0 \%$ & 9 & $22.0 \times$ & 0 & $0.0 \%$ & 1 & 2.48 & 41 & $100.0 \%$ \\
\hline & 小 計 & 48 & $36.9 \%$ & 51 & $39.2 \%$ & 25 & $19.2 \%$ & 2 & $1.5 \%$ & 4 & $3.1 \%$ & 130 & $100.0 \%$ \\
\hline \multirow{8}{*}{$\begin{array}{l}\text { 九 } \\
\text { 州 } \\
\text { 地 } \\
\text { 方 }\end{array}$} & 福岡県 & 9 & $18.0 \%$ & 27 & 54.08 & 11 & $22.0 \%$ & 3 & $6.0 \%$ & o) & $0.0 x$ & $50^{\prime}$ & 100.08 \\
\hline & 佐賀県 & 2 & 6.98 & 19 & $65.5 \%$ & 6 & 20.78 & 1 & $3.4 \%$ & 1. & 3.48 & 29 & $100.0 \%$ \\
\hline & 與崎県 & 4 & 11.48 & 20 & $57.1 \%$ & 7 & $20.0 \%$ & 4 & $11.4 \%$ & 0 & $0.0 \%$ & 35 & $100.0 \%$ \\
\hline & 熊本県 & 15 & $20.8 x$ & 35 & $48.6 \%$ & 20 & $27.8 \%$ & 2 & 2.88 & 0 & 0.08 & 72 & $100.0 \%$ \\
\hline & 大分県 & 13 & $39.4 x$ & 15 & $45.5 \%$ & 5 & 15.28 & 0 & $0.0 \%$ & 0 & $0.0 \%$ & 33 & $100.0 \%$ \\
\hline & 宮崎県 & 13 & 44.88 & 12 & 41.48 & 4 & $13.8 \%$ & 0 & $0.0 x$ & 0 & 0.08 & 29. & $100.0 \%$ \\
\hline & 鹿児島県 & 27 & $50.9 \%$ & 19 & $35.8 \%$ & 6 & $11.3 \times$ & 0 & $0.0 \%$ & 1 & $1.9 x$ & 53 & $100.0 \%$ \\
\hline & 小 㝇 & 83 & $27.6 \%$ & 147 & $48.8 \%$ & 59 & $\mid 19.68$ & 10 & $3.3 x$ & 2 & $0.7 x$ & 3011 & 100.08 \\
\hline
\end{tabular}

不正確ではあるが、中部以西の全県全市町村における概括的な傾向 を読みとることはできる。 


\section{2 同居以外のサポート居住の増加傾向}

住民課長の判断により、「隣居」「近居」「準近居」など同居以外の サポート居住の近年における増加傾向の有無について、「その傾向が 強くみられる」「ある程度みられる」「今後增加する兆倓がみられる」

「殆どみられない」「もとから同居以外が多く特に変わらない」のい ずれに該当するか、その回答分布を示したものが表 2 である。

中部、近畿、中国、四国、九州のいずれの地方においても、同居 以外の居住関係が増加する傾向が明らかであり、同居離れが全国的 に進んでいることが推察される。ただし、その動きは中部地方にお いてやや鈍く、近畿以西の西日本において顕著である。もともと西 日本は東日本に比較して同居傾向が低いとされてきたが、この調査 結果はそのことをある程度反映したものと解积できる。

\section{3 サポート居住類型別の増加傾向}

「隣居」「近居」「準近居」のいずれのサポート居住が増加傾向に あるかを複数回答で求めた結果が図 1 である。どの地方においても、 まず「近居」の増加が著しいことが認められる。それに「準近居」、

「隣居」が続く。

\section{4 就業構造と各サポート居住類型の発生傾向との相関}

各サポート居住類型の出現分布の傾向は各市町村毎に異なるが、 それは総じて第 2 次・第 3 次産業が集積するD I D 都市への就業依 存度の影響を受けることが予想される。そこで、試みに他市町村に 就業先を有する就業者の割合段階別に各市町村において最多数を占 めるサポート居住類型の割合をみると、図 2 のような結果になる。

これによると、自市町村内に就業先を有する就業者が多い地域ほ ぞ（その頂点がD I D都市と考えられる）「近居」が多く、逆に他市 町村への就業者が多い地域ほど（D I D 都市から離れるほどと考え られる）「準近居」が多い。「隣居」は強いて言えば「近居」に類似 した傾向を有するが、大幅な地域差は見られない。

\section{5 · 各サポート居住類型の出現率に影響を与える要因}

各サポート居住類型の出現率に影響を与える要因を回答者の自由 回答から拾い出すと、まず、子世帯が農業を継承せずサラリーマン になるなどの就業構造の変化、それに伴う居住地の変更により同居 の成立が困難となる。また、生活の近代化に伴い生じた親子両世帯 の生活サイクルや生活習慣のずれから同居が避けられるようになる。

親の家や土地が狭い、あるいは近接地に土地や住宅を確保できな いといった土地・住宅事情から「近居」や「準近居」が出現する場 合も少なくない。

住宅政策の影響も大きい。たとえば公営住宅等の整備が進むと、 子世帯が親元から離れ「近居」が促進される。さらに交通条件が良 くなると、DI D都市から離れた地域でも通勤の便が良くなり出身 市町村内にとどまるものが増加する一方、度々の帰省も苦にならな くなるため「準近居」が増え、二極分解の傾向もみられる。

このような居住関係は必ずしも固定的ではなく、ライフサイクル に応じてしばしば変化する。親世帯が若い間は「近居」「準近居」あ るいは「遠居」、親の加秢に伴い生活支援や介護のために徐々に親元 に近い場所に居を移す事例はその典型である。

\section{3. サポート居住および準近居の実態}

3. 1 調査概要

前記の住民課長向け調查を参考に、中部地方以西から 6 県を選択
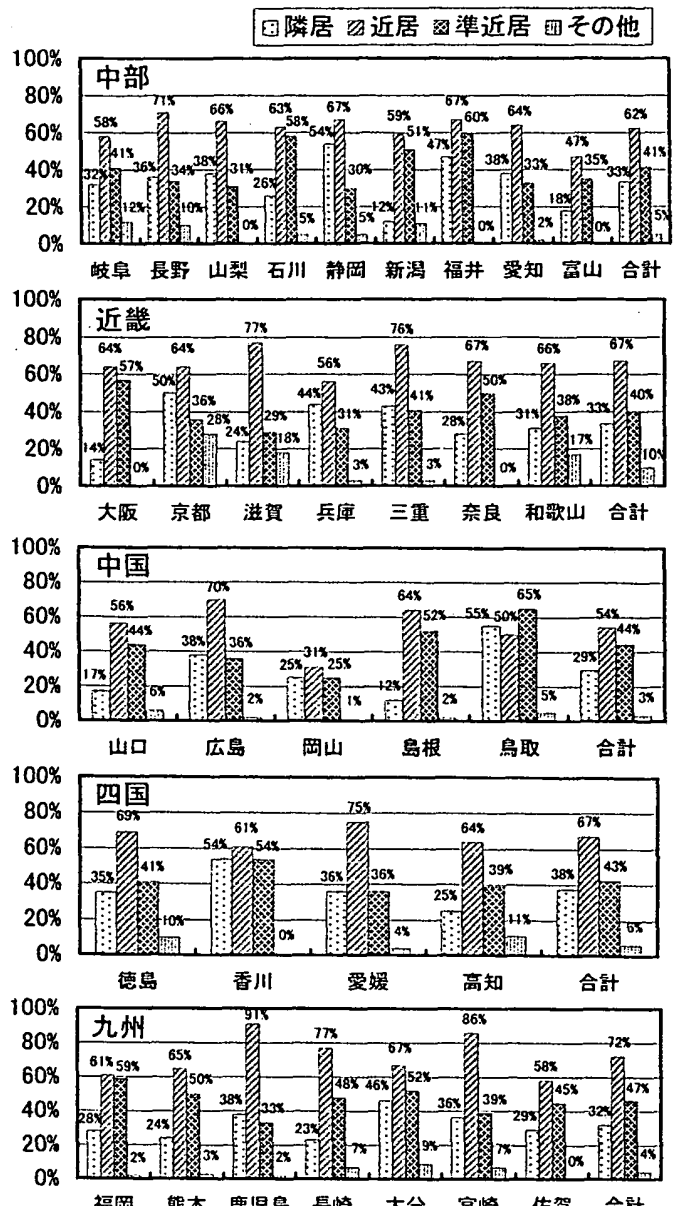

図1サポート居住類型別の増加傾向

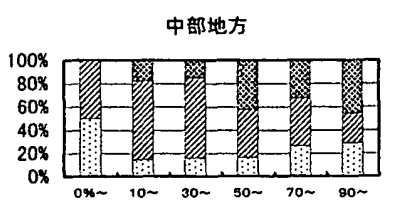

中国地方

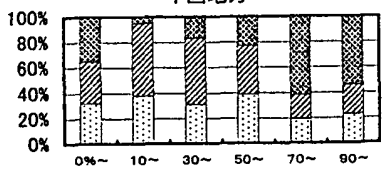

九州地方
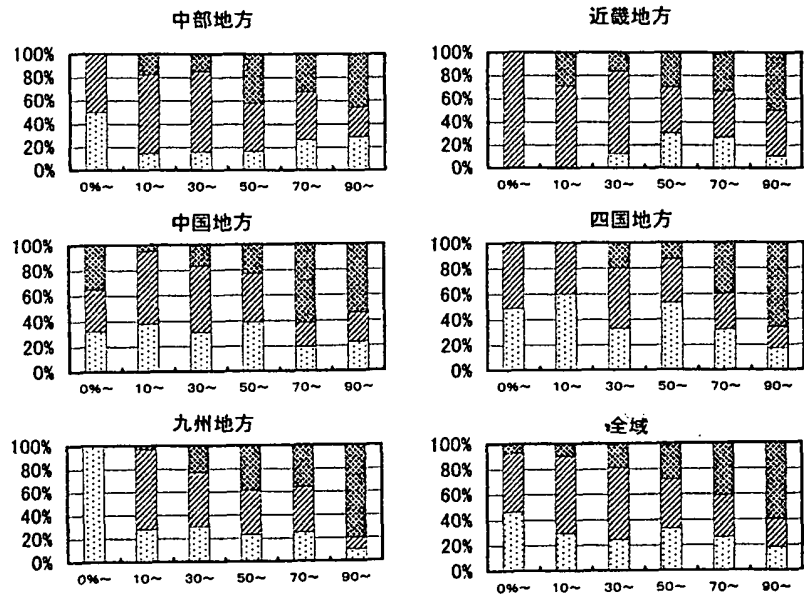

四国地方

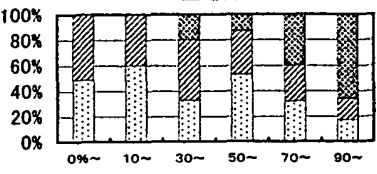

全城

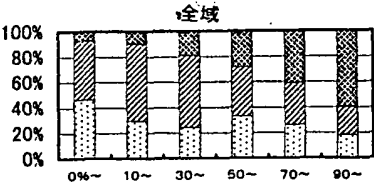

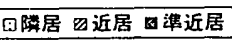

図2＼cjkstart他市町村への就業依存度とサポート居住との相関

し、各県内では中心都市と県縁辺部を結ぶ軸線上で $4 \sim 7$ の市町村、 計 32 市町村を抽出し、各市町村の民生委員を通じて、65 歳以上各 100 名を目途にアンケートを配布した。調査の基本的な項目は、「子世帯 との居住関係（サポート居住）、「親子両世帯の交流・支援の状況」、

「親世帯のサポートネットワークの状況」である。調査対象県名お よび市町村名を表 3 に示す。有効回収数は計 2,711 票（世帯）であ る。市町村別の有効回収数は表 8 に示す。 
表3調査摡要(民生委員による調登)

\begin{tabular}{|c|c|c|c|}
\hline 地方名 & 紧名 & 市町村名 & 睭查数 \\
\hline 中部地方 & 裸井鼠 & $\begin{array}{l}\text { 三国町、朝曰町、上志比村、越前町、膦山市、大野市 } \\
\text { 和泉村 }\end{array}$ & 7 \\
\hline 中国地方 & 岡山県 & 澋戸町、山手村、和気町、佐伯町、有漠町 & 5 \\
\hline \multirow{2}{*}{ 四国地方 } & 香川鼠 & 志度町。大内町。白鳥町。引田町 & 4 \\
\hline & 高知県 & 南国市、佐川町、安甚市、奈半利町、起知町、池川町 & 6 \\
\hline \multirow{2}{*}{ 九匆地方 } & 福岡県 & 筷紫野市、朝會町、広川町、立花町、上閣町、星野村 & 6 \\
\hline & 能本與 & 莱隄町、大津町、長樭町、高森町 & 4 \\
\hline 4地方 & 6県 & 32市町村 & 32 \\
\hline
\end{tabular}

3. 2 回答者(世帯)のプロフィール

回答者の世帯が夫婦健在か否かについてみると、夫婦健在の世帯 は52〜59\%、夫 1 人は 9 12\%、妻 1 人は $31 〜 36 \%$ 分布しており、 県別の差異はわずかである。（表 4）

年齢分布も、75 歳未満の前期高齢者が $49 \sim 55 \%$ 、後期高齢者が 40 〜 47\%と、県別による大幅な差異は認められない。なお、全国的デ 一夕(高齢社会白書・総務省平成 12 年調査、前期 $59 \%$ 、後期 $41 \%$ ) ${ }^{7}$ に比較すると後期高齢者が若干多目ではあるが、ほぼ同水準のサン プルが得られていると考えられる。（表 4）

有職率は、夫婦健在の夫が18～37\%と最も多い。次いで夫婦健在 の妻が $14 \sim 27 \%$ 。夫 1 人 $8 \sim 30 \%$ 、妻 1 人6〜14\%である。(表省略)

健康度については、夫婦健在の夫の 60 ～71\%が健康である。夫婦 健在の妻は $61 \sim 74 \%$ 、夫 1 人 $44 \sim 66 \%$ 、妻 1 人 $50 \sim 64 \%$ 、 男性より女性、単身より夫婦健在の方が健康度が高い。（表 5）

住宅形式は、ほとんどが戸建持家であるが、熊本県では公営住宅 が他に比較して多い。（表 6）

実子数は、全県平均でみると 2 人が最も多い。次いで 3 人である。 福岡県は 3 人が最頻值となっている。(表 7)

表4 年秢分布(夫婦健在の有無別)

\begin{tabular}{|c|c|c|c|c|c|c|c|c|c|}
\hline 県名 & 世带類型 & 65崖 & 未満 & 65歲以上 & 75歳以上 & 不 & 明 & & 㝇 \\
\hline \multirow{5}{*}{ 福井県 } & & & $0.0 \%$ & $15855.0 \%$ & $119 \mid 42.2 \%$ & 5 & $1.8 \%$ & & $100.0 \%$ \\
\hline & 妻 & 41 & $14.5 \%$ & $16357.8 \%$ & $75 \mid 26.6 \%$ & 3 & $1.1 \%$ & 282 & $100.0 \%$ \\
\hline & 夫のみ & 0 & $0.0 \%$ & $2047.6 x$ & $2252.4 \%$ & 0 & $0.0 \%$ & & $100.0 \%$ \\
\hline & 鼔のみ & & $0.6 \%$ & \begin{tabular}{|l|l|}
62 & $39.5 \%$ \\
\end{tabular} & \begin{tabular}{l|l|}
$99.9 \%$ \\
\end{tabular} & 0 & $0.0 \%$ & 157 & $100.0 \%$ \\
\hline & 小浢 & 42 & $5.5 \%$ & \begin{tabular}{|c|c|}
$403.8 \%$ \\
\end{tabular} & \begin{tabular}{|l|l|l|}
310 \\
\end{tabular} & 8 & $1.0 \%$ & 763 & $100.0 \%$ \\
\hline \multirow{5}{*}{ 岡山県 } & 夫 & $\overline{1}$ & $0.4 \%$ & $148.51 .9 \%$ & $134 / 47.0 \%$ & 2 & $0.7 \%$ & 285 & $100.0 \%$ \\
\hline & 車 & 28 & $9.8 \%$ & $16557.9 \%$ & $91 \mid 31.9 \%$ & 1 & $0.4 \%$ & & $100.0 \%$ \\
\hline & 夫のみ & 0 & $0.0 \%$ & \begin{tabular}{|l|l|}
$172.1 \%$ \\
\end{tabular} & $36,67.9 \%$ & 0 & $0.0 \%$ & 53 & $100.0 \%$ \\
\hline & 車のみ & 0 & $0.0 \%$ & \begin{tabular}{|l|l|l|}
58.78 \\
\end{tabular} & $92|61.36|$ & 0 & $0.0 \%$ & 150 & $100.0 \%$ \\
\hline & 小尌 & 29 & $3.8 \%$ & $388|50.2 \%|$ & \begin{tabular}{l|l}
$353 / 45.7 \%$ \\
\end{tabular} & 3 & $0.4 \%$ & 773 & $100.0 \%$ \\
\hline \multirow{5}{*}{ 香川県 } & 夫 & 0 & $0.0 \%$ & \begin{tabular}{|l|l|}
$83.0 \%$ \\
\end{tabular} & $\begin{array}{l}78 \mid 47.0 \% \\
\end{array}$ & 의 & $0.0 \%$ & 166 & $100.0 \%$ \\
\hline & 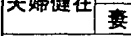 & 12 & $7.2 \%$ & \begin{tabular}{|l|l|}
$103.02 .0 \%$ \\
\end{tabular} & \begin{tabular}{|l|l|l|}
51 & $30.7 \%$ \\
\end{tabular} & 0 & $0.0 \%$ & 166 & $100.0 \%$ \\
\hline & 夫のみ & 0 & $0.0 \%$ & $15 \mid 41.7 \%$ & $2158.3 \%$ & 0 & $0.0 \%$ & 36 & $100.0 \%$ \\
\hline & 㤗のみ & 0 & $0.0 \%$ & 31 31.6\% & $67|68.4 \%|$ & 0 & $0.0 \%$ & 98 & $100.0 \%$ \\
\hline & 小暗 & 12 & $2.6 \%$ & $237|50.9 x|$ & \begin{tabular}{|l|l|}
217 & $46.6 \%$ \\
\end{tabular} & 0 & $0.0 \%$ & 466 & $100.0 \%$ \\
\hline \multirow{5}{*}{ 高知県 } & 夫 & & $0.4 \%$ & $127 \mid 49.8 \%$ & \begin{tabular}{|l|l|}
126 & $49.4 \%$
\end{tabular} & 1 & $0.4 \%$ & 255 & $100.0 \%$ \\
\hline & & & $12.2 \%$ & $148 \mid 58.0 \%$ & \begin{tabular}{l|l|}
$76.8 \%$ \\
\end{tabular} & 0 & $0.0 \%$ & 255 & $100.0 \%$ \\
\hline & 夫のみ & & $0.0 \%$ & $29 \mid 58.0 \%$ & $21 \mid 42.0 \%$ & 0 & $0.0 \%$ & & $100.0 \%$ \\
\hline & 雨のみ & 0 & $0.0 \%$ & $37(26.26)$ & \begin{tabular}{|l|l|}
$104.8 \%$ \\
\end{tabular} & 0 & $0.0 \%$ & 141 & $100.0 \%$ \\
\hline & 小部 & 32 & $4.6 \%$ & \begin{tabular}{|c|c|}
$341 / 48.6 \%$ \\
\end{tabular} & \begin{tabular}{|l|l|}
327 & $46.6 \%$ \\
\end{tabular} & 1 & $0.1 \%$ & 701 & $100.0 \%$ \\
\hline \multirow{5}{*}{ 福岡県 } & 夫 & & $0.0 \%$ & $199 \mid 62.0 \%$ & 12137.78 & 1 & $0.3 \%$ & 321 & $100.0 \%$ \\
\hline & & & $16.5 \%$ & $190 \mid 59.26$ & $75 \mid 23.4 \%$ & 3 & $0.9 \%$ & 321 & $100.0 \%$ \\
\hline & 夫のみ & 0 & $0.0 \%$ & $24 \mid 33.3 \%$ & \begin{tabular}{|l|l|}
66.78 \\
\end{tabular} & 0 & $0.0 \%$ & 72 & $100.0 \%$ \\
\hline & 罴のみ & 0 & $0.0 \%$ & $77 \mid 39.7 \%$ & $\begin{array}{l}11659.88 \\
\end{array}$ & 1 & $0.5 \%$ & 194 & $100.0 \%$ \\
\hline & 小計 & 53 & $5.8 \%$ & \begin{tabular}{|l|l|}
$490.0 \%$ \\
\end{tabular} & $360 \mid 39.6 \%$ & 5 & $0.6 \%$ & 908 & $100.0 \%$ \\
\hline \multirow{5}{*}{ 族本県 } & 夫 & 0 & $0.0 \%$ & \begin{tabular}{l|l|}
11252.36 \\
\end{tabular} & \begin{tabular}{|l|l|}
$985.8 \%$ \\
\end{tabular} & 4 & $1.9 \%$ & 214 & $100.0 \%$ \\
\hline & 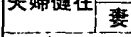 & 0 & $0.0 \%$ & $140|65.48|$ & \begin{tabular}{ll|l|l|}
702.78 & \\
\end{tabular} & 4 & $1.9 \%$ & 214 & $100.0 \%$ \\
\hline & 夫のみ & 0 & $0.0 \%$ & $17[36.26]$ & $3063.8 \%$ & 0 & $0.0 \%$ & 47 & $100.0 \%$ \\
\hline & 妻のみ & 0 & $0.0 \%$ & $7248.6 \%$ & $76151.4 \%$ & 0 & $0.0 \%$ & 148 & $100.0 \%$ \\
\hline & 小計 & 0 & $0.0 \%$ & \begin{tabular}{|l|l|}
341 & $54.7 \%$ \\
\end{tabular} & $274 \mid 44.0 \%$ & 8 & $1.3 \%$ & 623 & $100.0 \%$ \\
\hline & & 168 & $4.0 \%$ & $2200 \mid 52.0 \%$ & $1841 \mid 43.5 \%$ | & 25 & $0.6 x$ & 4234 & $100.0 \%$ \\
\hline
\end{tabular}

表5 健康度 (夫婦健在の有無別)

\begin{tabular}{|c|c|c|c|c|c|c|c|c|c|c|c|}
\hline 䢐名 & 世带類型 & \multicolumn{2}{|c|}{ 健康 } & \multicolumn{2}{|c|}{ 通院中 } & \multicolumn{2}{|c|}{ 要介镜 } & \multicolumn{2}{|c|}{ 不明 } & \multirow{2}{*}{\multicolumn{2}{|c|}{\begin{tabular}{c|c}
\multicolumn{1}{c}{$8 t$} \\
282 & $100.0 \%$ \\
\end{tabular}}} \\
\hline \multirow{5}{*}{ 福井県 } & & 172 & $61.0 \%$ & 67 & $23.8 \%$ & 23 & $8.2 \%$ & 20 & 7.18 & & \\
\hline & 亪 & 177 & $62.8 \%$ & 71 & $25.2 \%$ & 16 & $5.7 \%$ & 18 & $6.4 \%$ & 282 & $100.0 \%$ \\
\hline & 夫のみ & 27 & $64.3 \%$ & 6 & $14.3 \%$ & 6 & $14.3 \%$ & 3 & $7.1 \%$ & 42 & $100.0 \%$ \\
\hline & 辆のみ & 91 & $58.0 \%$ & 37 & $23.6 \%$ & 19 & 12.18 & 10 & $6.4 \%$ & 157 & $100.0 \%$ \\
\hline & 小尌 & 467 & $61.2 \%$ & 181 & $23.7 \%$ & 64 & $8.4 \%$ & 51 & 6.78 & & $100.0 \%$ \\
\hline \multirow{5}{*}{ 岡山巢 } & 夫嵒健在 夫 & 184 & $64.6 \%$ & 74 & $26.0 \%$ & 12 & $4.2 \%$ & 15 & $5.3 \%$ & 285 & $100.0 \%$ \\
\hline & & 203 & $71.2 \%$ & 55. & $19.3 \%$ & 19 & 6.78 & 8 & $2.8 \%$ & 285 & $5100.0 \%$ \\
\hline & 夫のみ & 29 & $54.7 \%$ & 16. & $30.2 \%$ & 7 & $13.2 \%$ & 1 & $1.9 \%$ & 53 & $100.0 \%$ \\
\hline & 霆のみ & 96 & $64.0 \%$ & 35 & $23.3 \%$ & 14 & $9.3 x$ & 5 & $3.3 \%$ & 150 & $100.0 \%$ \\
\hline & 小訲 & 512 & $66.2 \%$ & 180 & $23.3 \%$ & 52 & $6.7 \%$ & 29 & $3.8 \%$ & 773 & $100.0 \%$ \\
\hline \multirow{5}{*}{ 香川県 } & 绳傅在夫 & 115 & $69.3 \%$ & 33 & $19.9 \%$ & 11 & $6.6 \%$ & 7 & $4.2 \%$ & 166 & $100.0 \%$ \\
\hline & 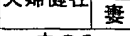 & 102 & $61.4 \%$ & 35 & $21.1 \%$ & 20 & $12.0 \%$ & 9 & $5.4 \%$ & 166 & $100.0 \%$ \\
\hline & 夫のみ & 16 & $44.4 \%$ & 16 & $44.4 \%$ & 4 & $11.1 \%$ & 0 & $0.0 \%$ & & $100.0 \%$ \\
\hline & 橆のみ & 56 & $57.1 \%$ & 22 & 22.48 & 16 & $16.3 \%$ & 4 & $4.1 \%$ & 98 & $100.0 \%$ \\
\hline & 小㖕 & 289 & $62.0 \%$ & 106 & $22.7 \%$ & 51 & $10.9 \%$ & 20 & $4.3 \%$ & 466 & $100.0 \%$ \\
\hline \multirow{5}{*}{ 离知桨 } & 夫 & 154 & $60.4 x$ & 81 & $31.8 \%$ & 16 & $6.3 \%$ & 4 & $1.6 \%$ & 255 & $100.0 \%$ \\
\hline & & 172 & $67.5 \%$ & 61 & $23.9 \%$ & 10 & $3.9 \%$ & 12 & 4.78 & 255 & $100.0 \%$ \\
\hline & 夫のみ & 33 & $66.0 \%$ & 15 & $30.0 \%$ & 0 & $0.0 \%$ & 2 & $4.0 \%$ & & $100.0 \%$ \\
\hline & 䢂のみ & 71 & $50.4 \%$ & 46 & $32.6 \%$ & 14 & $9.9 \%$ & 10 & $7.1 \%$ & 141 & $100.0 \%$ \\
\hline & 小斯 & 430 & $61.3 \%$ & 203 & $29.0 \%$ & 40 & $5.7 \%$ & 28 & $4.0 \%$ & & $100.0 \%$ \\
\hline \multirow{5}{*}{ 福岡県 } & 夫 & 217 & $67.6 \%$ & 72 & $22.4 \%$ & 18 & $5.6 \%$ & 14 & $4.4 \%$ & 321 & $100.0 \%$ \\
\hline & 证地 & 214 & $66.7 \%$ & 74 & $23.1 \%$ & 15 & 4.78 & 18 & $5.6 \%$ & 321 & $100.0 \%$ \\
\hline & 夫のみ & 38 & $52.8 \%$ & 20 & $27.8 \%$ & 5 & $6.9 \%$ & 9 & $12.5 \%$ & 72 & $100.0 \%$ \\
\hline & 萋のみ & 104 & $53.6 \%$ & 56 & $28.9 \%$ & 22. & $11.3 \%$ & 12 & $6.2 \%$ & 194 & $100.0 \%$ \\
\hline & 小勘 & 573 & $63.1 \%$ & 222 & $24.4 \%$ & 60 & $6.6 \%$ & 53 & $5.8 \%$ & 908 & $100.0 \%$ \\
\hline \multirow{5}{*}{ 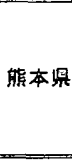 } & 夫 & 127 & $59.3 \%$ & 51 & $23.8 \%$ & 17] & $7.9 \%$ & 19 & $8.9 \%$ & 214 & $100.0 \%$ \\
\hline & 传 & 133 & 62.18 & 53 & $24.8 \%$ & 9 & $4.2 \%$ & 19 & $8.9 \%$ & 214 & $100.0 \%$ \\
\hline & 天のみ & 27 & 57.48 & 15 & $31.9 \%$ & 5 & 10.68 & 0 & $0.0 \%$ & 47 & $100.0 \%$ \\
\hline & 姲のみ & 82 & $55.4 \%$ & 45 & $30.4 \%$ & 13 & $8.8 \%$ & 8 & $5.4 \%$ & 148 & $100.0 \%$ \\
\hline & 小訲 & 369 & $59.2 \%$ & 164 & $26.3 \%$ & 44) & 7.18 & 46 & $7.4 \%$ & 623 & $100.0 \%$ \\
\hline & 合部 & 2640 & $62.4 \%$ & 056 & $24.9 \%$ & 311 & $7.3 \%$ & 227 & $5.4 x$ & 4234 & $100.0 \%$ \\
\hline
\end{tabular}

表6 住宅形式

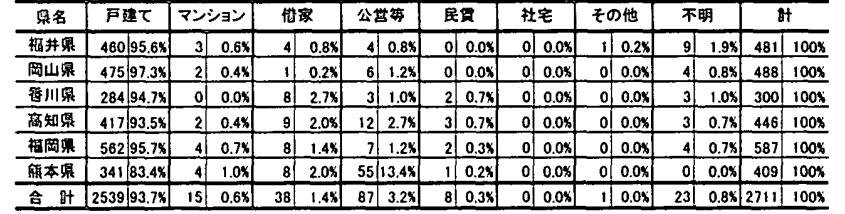

表7 実子数

\begin{tabular}{|c|c|c|c|c|c|c|c|c|c|}
\hline 景名 & $7+2 L$ & 11 & $2 \lambda$ & $3 \lambda$ & $4 \lambda$ & $5 \hat{2} \sim$ & 不明 & Bf & 军的黑于 \\
\hline 极井綮 & \begin{tabular}{l|l}
32 & 6.77 \\
\end{tabular} & $62.12 .9 x$ & 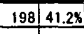 & $13127.2 x$ & \begin{tabular}{l|l}
35 & 7.36 \\
\end{tabular} & $\begin{array}{ll}15 & 3.116 \\
\end{array}$ & \begin{tabular}{l|l}
81.78 \\
\end{tabular} & \begin{tabular}{l|l|l|}
481 & 1000
\end{tabular} & 2.25 \\
\hline 周山果 & & $\begin{array}{ll}70 & 14.38 \\
\end{array}$ & $240 \mid 49.28$ & 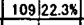 & $285.7 x$ & $14 \mid 2.98$ & $40.8 x$ & $100 x$ & 2.19 \\
\hline 整川果 & \begin{tabular}{l|l}
17 & 5.77 \\
\end{tabular} & $\begin{array}{ll}58 & 19.37 \\
\end{array}$ & $12441.3 x$ & $76 \mid 25.3 \mathrm{~K}$ & \begin{tabular}{l|l}
14 & $4.7 x$ \\
\end{tabular} & $\begin{array}{cl}10 & 3.38\end{array}$ & $0.3 x$ & 1005 & \\
\hline 夠知果 & & $89920.0 x$ & $\begin{array}{ll}192 \\
23.08\end{array}$ & $83 / 18.6 x$ & & 112.58 & $\begin{array}{ll}7 \mid 1.68 \\
\end{array}$ & \begin{tabular}{l|l|l|}
460 & 1005
\end{tabular} & 1.98 \\
\hline 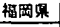 & & $9.0 x$ & $\begin{array}{ll}192 & 32.78\end{array}$ & $208355.4 \mathrm{X}$ & $73 \mid 12.48$ & $\begin{array}{l}244.18 \\
\end{array}$ & 5 & \begin{tabular}{|l|l|}
587 & 1000
\end{tabular} & 2.53 \\
\hline 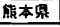 & \begin{tabular}{r|r}
28 & 6.87 \\
\end{tabular} & \begin{tabular}{l|l}
60 & 14.78
\end{tabular} & $12931.5 x$ & 113227,68 & $531,13.08$ & $235.6 x$ & 30.78 & \begin{tabular}{|l|l|}
409 & 1008 \\
\end{tabular} & \\
\hline & & & & & & & & \begin{tabular}{l|l}
711 & 1008
\end{tabular} & 227 \\
\hline
\end{tabular}

\section{3 サポート居住類型の発生分布}

\section{3.1 サポート居住類型の判定基準}

各サポート居住類型の判定基準は、下記のとおりとした。なお、 本稿の冒頭において、隻近居は、「子世帯が親元と就業地との中間地 に居を構えるもの」との定義を示したが、ここでは、実態から大き く離れることなく、かつ判別のし易さを考慮して、便宜的に「親世 帯と同県内居住」のものを準近居とみなすこととした。

同居 : 親世帯と子世帯が同棟居住のもの

隣居 ： 敷地内別棟または隣接敷地居住のもの

近居：同じ市町村内に居住するもの

準近居 : 同じ県内に居住するもの

遠居 ： 県外に居住するもの 


\section{3.2 サポート居住類型の発生分布}

全体的には「同居」の占有率が高いものの、県別にみると $25 \sim 48 \%$ と幅がある。福井県と福岡県における「同居」の比率が高い。岡山県 と高知県は低く、「準近居」を下回るか、せいぜい同程度にとどまる。 東日本の事例が福井県のみであるので断定することは難しいが、国 調も示すように、「同居」は東日本に厚く、西日本に薄いという事実 は今回の調査でも概ね立証された。(表 8)

「同居」に次ぎ全体での占有率が高いのは「準近居」であり、14 36 \%と「同居」に迫る比率を占める。「準近居」が最頻値またはそれに 近いのは岡山県と高知県である。

また、表 8 では、各県とも中心都市に近い市町村から顝に上から 並べているが、中心都市（県庁所在地）より離れるほど「準近居」 の占有率が高くなる傾向が認められる。前章において、準近居は中 心都市への就業指向と親世帯への配慮とのバランスの上に成立する 居住関係と仮定したが、データはこの準近居の仮説が的はずれでは なかったことを立証している。

他のサポート居住類型については、「隣居」が4〜 16\%、「近居」 が8〜19\%、「遠居」が7〜18\%と大同小異である。「隣居」が相対的
に多いのは香川県と高知県である。㩊居慣行の名残りと推察される。 なお前章で、住民課長へのアンケートでは.「近居」の増加傾向が 最も著しいとの回答結果を述べたが、上記のように、絶対数として はそれほど「近居」が突出しているわけではないことが判明した。

\section{4 子供の続柄とサポート居住類型の相関}

「同居」から「遠居」の間で第 1 番目に出現する子供との居住関 倸に限定して、その続柄とサポート居住類型との相関をみた。

ほほ全てのサポート居住類型において長男の占める比率が高い。 特に「同居」では62〜 72\%と高率である。しかし長女の比率も少な くはない。特に、「近居」と「準近居」においては長男と匹敵する比 率を占める。また、「近居」において次女の比率もやや目立つ。次男 以下にも同種の傾向がうかがわれる。すなわち、長男だけではなく、 嫁ぎ先が近在に限定されることの多い女子も含めて、親世帯のサポ 一トネットワークが形成されており、それが「準近居」および「近 居」といつたつかず離れずの居住関係が増加する要因にもなつてい ることが理解できる。(表 9)

「準近居」がこのような親のサポートを念頭において選択された 居住関倸であることは、子世帯が「準近居」を選択する際、親への

表8 サポート居住類型(居住関係類型)

\begin{tabular}{|c|c|c|c|c|c|c|c|c|c|c|c|c|c|c|c|c|c|c|c|c|c|}
\hline 県名 & 市町村名 & & & & $\begin{array}{l}\text { 居 } \\
\text { 昏子) }\end{array}$ & （既 & & （陪 & & & & & 丘居 & & 居 & & $\alpha$ & & & t & it \\
\hline \multirow{8}{*}{ 福井県 } & 三国町 & 28 & $37.3 \%$ & 11 & $14.7 \%$ & 2 & $2.7 \%$ & 0 & $0.0 \%$ & 10 & 13.3\% & 7 & $9.3 \%$ & 11 & $14.7 \%$ & 6 & $8.0 \%$ & 0 & $0.0 \%$ & 75. & $100.0 \%$ \\
\hline & 朝日町 & 38 & $47.5 \%$ & 3 & $3.8 \%$ & 4 & $5.0 \%$ & 0 & $0.0 \%$ & 8 & $10.0 \%$ & 11 & $13.8 \%$ & 5 & $6.3 \%$ & 6 & $7.5 \%$ & 5 & $6.3 \%$ & 80 & $100.0 \%$ \\
\hline & 上志比村 & 37 & 62.78 & 5 & $8.5 \%$ & 4 & $6.8 \%$ & 0 & $0.0 \%$ & 2 & $3.4 \%$ & 3 & $5.1 \%$ & 5 & $8.5 \%$ & 1 & $1.7 \%$ & 2 & $3.4 \%$ & 59 & $100.0 \%$ \\
\hline & 越前町 & 25 & $34.2 \%$ & 5 & $6.8 \%$ & 2 & $2.7 \%$ & 0 & 0.08 & 11 & $15.1 \%$ & 15 & $20.5 \%$ & 6 & $8.2 \%$ & 6 & $8.2 \%$ & 3 & $4.1 \%$ & 73 & $100.0 \%$ \\
\hline & 勝山市 & 9 & $13.0 \%$ & 3 & $4.3 \%$ & 4 & $5.8 \%$ & 1 & $1.4 \%$ & 11 & $.15 .9 \%$ & 18 & $26.1 \%$ & 15 & 21.78 & 5 & $7.2 \%$ & 3 & $4.3 \%$ & 69 & $100.0 \%$ \\
\hline & 大野市 & 31 & 54.48 & 3 & $5.3 \%$ & 1 & $1.8 \%$ & 0 & $0.0 \%$ & 6 & $10.5 \%$ & 5 & $8.8 \%$ & 5 & $8.8 \%$ & 3 & $5.3 \%$ & 3 & $5.3 \%$ & 57 & $100.0 \%$ \\
\hline & 和泉村、 & 9 & $13.2 \%$ & 6 & $8.8 \%$ & 3 & 4.4\% & 1 & $1.5 \%$ & 5 & $7.4 \%$ & 22 & $32.4 \%$ & 14 & $20.6 \%$ & 5 & $7.4 \%$ & 3 & $4.4 \%$ & 68 & $100.0 \%$ \\
\hline & 小計 & 177 & $36.8 \%$ & 36 & $7.5 \%$ & 20 & 4.2\% & 2 & $0.4 \%$ & 53 & $11.0 \%$ & 81 & $16.8 \%$ & 61 & $12.7 \%$ & 32 & $6.7 \%$ & 19 & $4.0 \%$ & 481 & $100.0 \%$ \\
\hline \multirow{6}{*}{ 岡山県 } & 瀬戸町 & 22 & $23.4 \%$ & 3 & $3.2 \%$ & 4 & $4.3 \%$ & 0 & $0.0 \%$ & 8 & $8.5 \%$ & 28 & $29.8 \%$ & 20 & $21.3 \%$ & 9 & $9.6 \%$ & 0 & $0.0 \%$ & 94 & $100.0 \%$ \\
\hline & 山手村 & 32 & $33.0 \%$ & 4 & $4.1 \%$ & 10 & $10.3 \%$ & 0 & $0.0 \%$ & 9 & $9.3 \%$ & 17 & $17.5 \%$ & 19 & $19.6 \%$ & 4 & $4.1 \%$ & 2 & $2.1 \%$ & 97 & $100.0 \%$ \\
\hline & 和㲷町 & 13 & $13.5 \%$ & 5 & $5.2 \%$ & 4 & $4.2 \%$ & 1 & $1.0 \%$ & 13 & $13.5 \%$ & 26 & $27.1 \%$ & 24 & $25.0 \%$ & 6 & $6.3 \%$ & 4 & $4.2 \%$ & 96 & $100.0 \%$ \\
\hline & 佐伯町 & 17 & $18.5 \%$ & 2 & $2.2 \%$ & 8 & $8.7 \%$ & 2 & $2.2 \%$ & 17 & $18.5 \%$ & 37 & $40.2 \%$ & 8 & $8.7 \%$ & 0 & 0.08 & 1 & $1.1 \%$ & 92 & $100.0 \%$ \\
\hline & 有璂町 & 24 & $22.0 \%$ & 5 & 4.6\% & 4. & $3.7 \%$ & 0 & $0.0 \%$ & 6 & $5.5 \%$ & 48 & $44.0 \%$ & 16 & $14.7 \%$ & 4 & 3.78 & 2 & $1.8 \%$ & 109 & $100.0 \%$ \\
\hline & 小斯 & 108 & $22.1 \%$ & 19 & $3.9 \%$ & 30 & $6.1 \%$ & 3 & $0.6 \%$ & 53 & $10.9 \%$ & 156 & $32.0 \%$ & 87 & $17.8 \%$ & 23 & 4.7\% & 9 & $1.8 \%$ & 488 & $100.0 \%$ \\
\hline \multirow{5}{*}{ 香川県 } & 志度町 & 24 & $30.0 \%$ & 10 & $12.5 \%$ & 7 & $8.8 \%$ & 0 & $0.0 \%$ & 17 & $21.3 \%$ & 11 & $13.8 \%$ & 8 & $10.0 \%$ & 2 & $2.5 \%$ & 1 & $1.3 \%$ & 80 & $100.0 \%$ \\
\hline & 大内町 & 16 & $24.6 \%$ & 6 & $9.2 \%$ & 11 & $16.9 \%$ & 2 & $3.1 \%$ & 12 & $18.5 \%$ & -4 & $6.2 \%$ & 9 & $13.8 \%$ & 4 & $6.2 \%$ & 1 & $1.5 \%$ & 65 & $100.0 \%$ \\
\hline & 白烏町 & 17 & $22.4 \%$ & 6 & $7.9 \%$ & 11 & $14.5 \%$ & 0 & 0.08 & 16 & $21.1 \%$ & 12 & $15.8 \%$ & 7 & $9.2 \%$ & 6 & $7.9 \%$ & 1 & $1.3 \%$ & 76 & $100.0 \%$ \\
\hline & 引田町 & 15 & $19.0 \%$ & 13 & $16.5 \%$ & 7 & $8.9 \%$ & 0 & $0.0 \%$ & 9 & $11.4 \%$ & 15 & $19.0 \%$ & 14 & 17.78 & 5 & $6.3 \%$ & 1 & $1.3 \%$ & 79 & $100.0 \%$ \\
\hline & 小虫 & 72 & $24.0 \%$ & 35 & 11.78 & 36 & $12.0 \%$ & 2 & 0.78 & 54 & $18.0 \%$ & 42 & $14.0 \%$ & 38 & $12.7 \%$ & 17. & $5.7 \%$ & 4 & $1.3 \%$ & 300 & $100.0 \%$ \\
\hline \multirow{7}{*}{ 高知県 } & 南国市 & 12 & $15.0 \%$ & 10 & $12.5 \%$ & 14 & $17.5 \%$ & 3 & $3.8 \%$ & 14 & $17.5 \%$ & 15 & $18.8 \%$ & 7 & $8.8 \%$ & 5 & $6.3 \%$ & 0 & $0.0 \%$ & 80 & $100.0 \%$ \\
\hline & 佐川町 & 12 & $15.0 \%$ & 8 & $10.0 \%$ & 20 & $25.0 \%$ & 5 & $6.3 \%$ & 9 & $11.3 \%$ & 17 & $21.3 \%$ & 3 & $3.8 \%$ & 5 & $6.3 \%$ & 1 & $1.3 \%$ & 80 & $100.0 \%$ \\
\hline & 安芸市 & 7 & $12.3 \%$ & 2 & $3.5 \%$ & 10 & $17.5 \%$ & 0 & $0.0 \%$ & 16 & $28.1 \%$ & 15 & 26.38 & 3 & $5.3 \%$ & 3 & $5.3 \%$ & 1 & $1.8 \%$ & 57 & $100.0 \%$ \\
\hline & 奈半利町 & 8 & $10.1 \%$ & 11 & $13.9 \%$ & 9 & $11.4 \%$ & 0 & $0.0 \%$ & 14 & $17.7 \%$ & 10 & 12.7\% & 10 & $12.7 \%$ & 16 & $20.3 \%$ & 1 & $1.3 \%$ & 79 & $100.0 \%$ \\
\hline & 越知町 & 19 & $24.1 \%$ & 8 & $10.1 \%$ & 3 & $3.8 \%$ & 0 & $0.0 \%$ & 8 & $10.1 \%$ & 22 & $27.8 \%$ & 4 & $5.1 \%$ & 5 & $6.3 \%$ & 10 & $12.7 \%$ & 79 & $100.0 \%$ \\
\hline & 池川町 & 11 & $15.5 \%$ & 4 & $5.6 \%$ & 6 & $8.5 \%$ & 1. & $1.4 \%$ & 8 & $11.3 \%$ & 24 & $33.8 \%$ & 10 & $14.1 \%$ & 7 & $9.9 \%$ & 0 & $0.0 \%$ & 71 & $100.0 \%$ \\
\hline & 小計 & 69 & $15.5 \%$ & 43 & $9.6 \%$ & 62 & 13.9\% & 9 & $2.0 \%$ & 69 & $15.5 \%$ & 103 & $23.1 \%$ & 37 & $8.3 x$ & 41 & $9.2 \%$ & 13 & $2.9 \%$ & 446 & $100.0 \%$ \\
\hline \multirow{7}{*}{ 福岡県 } & 筑紫野市 & 36 & $30.5 \%$ & 11 & $9.3 \%$ & 6 & $5.1 \%$ & 0 & $0.0 \%$ & 16 & $13.6 \%$ & 30 & $25.4 \%$ & 15 & $12.7 \%$ & 4 & $3.4 \%$ & 0 & $0.0 \%$ & 118 & $100.0 \%$ \\
\hline & 朝合町 & 38 & $48.1 \%$ & 12 & $15.2 \%$ & 4 & $5.1 \%$ & 0 & $0.0 \%$ & 1 & $1.3 \%$ & 14 & $17.7 \%$ & 4 & $5.1 \%$ & 3 & $3.8 \%$ & 3 & $3.8 \%$ & 79 & $100.0 \%$ \\
\hline & 広川町 & 29 & $28.7 \%$ & 11 & $10.9 \%$ & 3 & $3.0 \%$ & 0 & $0.0 \%$ & 9 & $8.9 \%$ & 26 & $25.7 \%$ & 9 & $8.9 \%$ & 10 & $9.9 \%$ & 4 & $4.0 \%$ & 101 & $100.0 \%$ \\
\hline & 立花町 & 56 & $57.1 \%$ & 7 & $7.1 \%$ & 1 & $1.0 \%$ & 0 & $0.0 \%$ & 7 & $7.1 \%$ & 17 & $17.3 \%$ & 4 & 4.1\% & 4 & $4.1 \%$ & 2 & $2.0 \%$ & 98 & $100.0 \%$ \\
\hline & 上陽町 & 46 & $48.9 \%$ & 10 & $10.6 \%$ & 1. & $1.1 \%$ & 1 & $1.1 \%$ & 1 & $1.1 \%$ & 20 & $21.3 \%$ & 5 & $5.3 \%$ & 6 & $6.4 \%$ & 4 & $4.3 \%$ & 94 & $100.0 \%$ \\
\hline & 星野村 & 18 & $18.6 \%$ & 5 & $5.2 \%$ & 7 & $7.2 \%$ & 0 & $0.0 \%$ & 14 & $14.4 \%$ & 39 & $40.2 \%$ & 6 & $6.2 \%$ & 5 & $5.2 \%$ & 3 & $3.1 \%$ & 97 & $100.0 \%$ \\
\hline & 小訲 & 223 & $38.0 \%$ & 56 & $9.5 \%$ & 22 & $3.7 \%$ & 1 & $0.2 \%$ & 48 & $8.2 \%$ & 146 & $24.9 \%$ & 43 & $7.3 \%$ & 32 & $5.5 \%$ & 16 & $2.7 \%$ & 587 & $100.0 \%$ \\
\hline \multirow{5}{*}{ 䈍本県 } & 莱陽町 & 8 & $9.1 \%$ & 6 & $6.8 \%$ & 4 & $4.5 \%$ & 2 & $2.3 \%$ & 17 & $19.3 \%$ & 34 & $38.6 \%$ & 9 & $10.2 \%$ & 4 & $4.5 \%$ & 4 & $4.5 \%$ & 88 & $100.0 \%$ \\
\hline & 大津町 & 17 & $16.5 \%$ & 2 & $1.9 \%$ & 5 & $4.9 \%$ & 0 & $0.0 \%$ & 31 & $30.1 \%$ & 32 & $31.1 \%$ & 10 & $9.7 \%$ & 5 & $4.9 \%$ & 1 & $1.0 \%$ & 103 & $100.0 \%$ \\
\hline & 長陽村 & 13 & $11.1 \%$ & 8 & $6.8 \%$ & 3 & $2.6 \%$ & 1 & $0.9 \%$ & 19 & $16.2 \%$ & 43 & $36.8 \%$ & 16 & $13.7 \%$ & 14 & $12.0 \%$ & 0 & $0.0 \%$ & 117 & $100.0 \%$ \\
\hline & 高森町 & 19 & $18.8 \%$ & 6 & $5.9 \%$ & 4. & $4.0 \%$ & 0 & $0.0 \%$ & 12 & $11.9 \%$ & 39 & $38.6 \%$ & 16 & $15.8 \%$ & 5 & $5.0 \%$ & 0 & $0.0 \%$ & 101 & $100.0 \%$ \\
\hline & 小計 & 57 & $13.9 \%$ & 22 & $5.4 \%$ & 16 & $3.9 \%$ & 3. & $0.7 \%$ & 79 & $19.3 \%$ & 148 & $36.2 \%$ & 51 & $12.5 \%$ & 28 & $6.8 \%$ & 5 & $1.2 \%$ & 409 & $100.0 \%$ \\
\hline \multicolumn{2}{|c|}{ 合㖕 } & 706 & $26.0 \%$ & 211 & $7.8 \%$ & 186 & $6.9 \%$ & 20 & $0.7 \%$ & 356 & $13.1 \%$ & 676 & $24.9 \%$ & 317 & $11.7 \%$ & 173 & $6.4 \%$ & 66 & $2.4 \%$ & 2711 & $100.0 \%$ \\
\hline
\end{tabular}

注）各県共に、中心都市に近い市町村から順番に上から配列している。 
表9子供の続柄とサポート居住類型の相闦
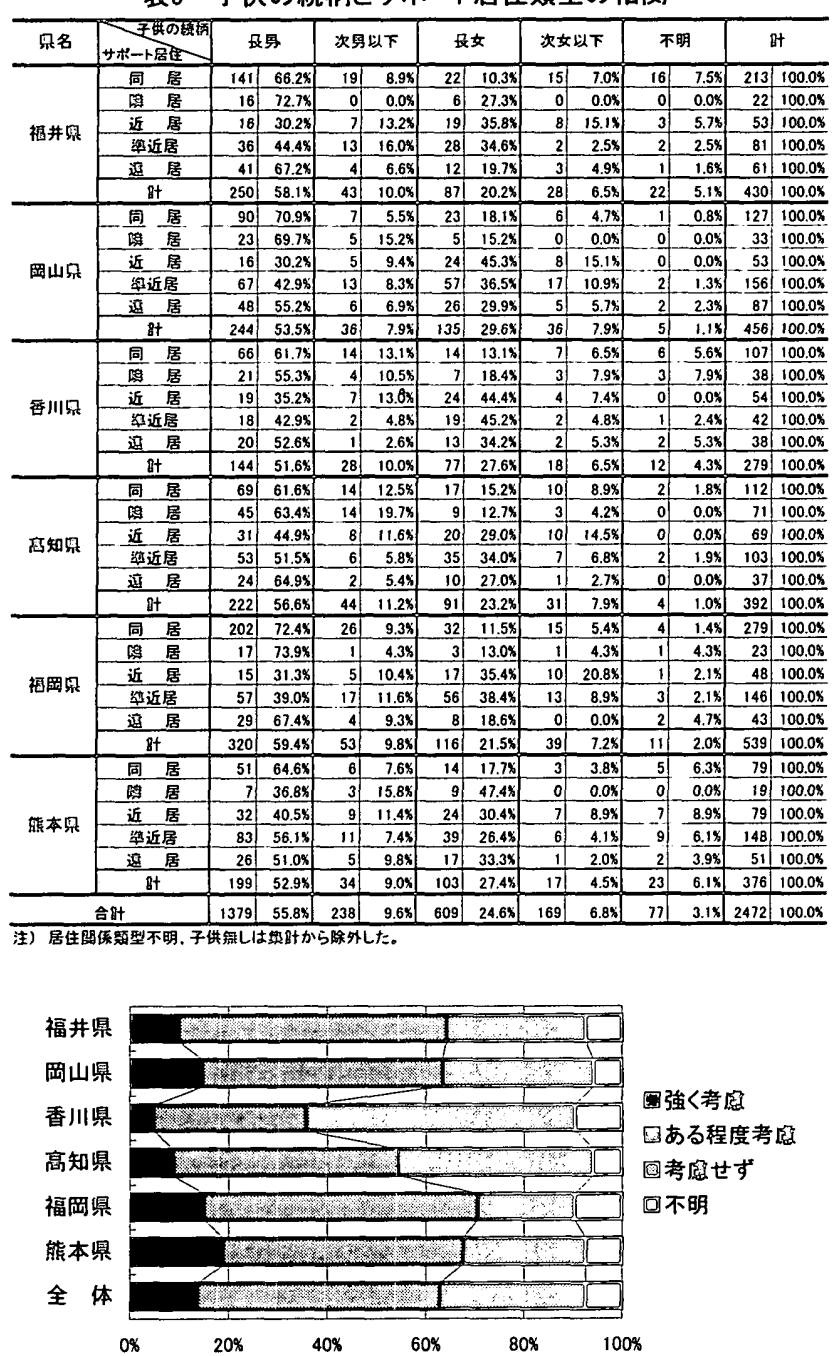

図3 居住地選定時の親への配慮(準近居の場合)

支援や接触のし易さを考慮したか否かとの設問に対し、考慮したと するものが60\%を越えていることからもうかがわれる。（図 3）

このようなネットワークの存在が、たとえ配偶者に先立たれても それが必ずしも直ぐさま子世帯との「同居」に移行しないことの一 つの要因を成していると思われる。表 10 は、夫婦健在の場合とそう でない場合とを比較したものであるが、配偶者がいなくても必ずし も「同居」が多いわけではなく、このことを豪付けている。むしろ、 親は気楽さを求めて、多少離れて暮らすことを積極的に指向してい る面もあると考えられる。

\section{5 将禁の居住関係についての希望}

現在、子世帯と「近居」の関係にある親世帯では、「今のままでよ いよとるものが、熊本県の $49 \%$ を除けば、圧倒的多数であり、81 〜88\%を占めている。また、「準近居」においても、熊本県の53\%を 除けぱ、62〜90\%とかなりの高水準である。「遠居」ではさすがにそ の比率は低下し、57〜79\%となる。（図 4)

この結果を単純に解採することはできない。一般的には、諸般の 事情から子世帯と離れて暮らすことを「仕方がない」と諦観してい るとみなすべきかもしれない。しかし一方で、上述のように離れて 暮らすことの気楽さも積極的に認めているとも解釈できなくもない。
落10 去螮健在か否かとサポート居住類型の相関

\begin{tabular}{|c|c|c|c|c|c|c|c|c|c|c|c|c|}
\hline 只名 & 世茾彩型 & 同居 & 路 & & 近居 & 淮近居 & 莩层 & 倨 & & 明 & & 84 \\
\hline \multirow{4}{*}{ 相井只 } & 夫䀦蚂在 & 13851.18 & & 3.78 & \begin{tabular}{ll|l}
30 & 11.18 \\
\end{tabular} & \begin{tabular}{l|l|l|l|}
50 & 18.58 \\
\end{tabular} & & 11.98 & 10 & $3.7 x$ & 270 & $100.0 \%$ \\
\hline & 夫のみ & \begin{tabular}{l|l|}
15 & 45.58 \\
\end{tabular} & & 12.18 & \begin{tabular}{|l|l|}
3 & 9.18 \\
\end{tabular} & \begin{tabular}{l|l|}
4 & 12.18 \\
\end{tabular} & & $15.2 x$ & & $6.1 x$ & 33 & $100.0 \%$ \\
\hline & 医のみ & $60 \mid 41.18$ & 8 & $5.5 x$ & \begin{tabular}{ll|l|}
20 & 13.78 \\
\end{tabular} & \begin{tabular}{|l|l|l|}
27 & 18.58 \\
\end{tabular} & & $16.4 \times$ & 7 & 4.88 & 146 & $100.0 \times$ \\
\hline & Bt & $213 \mid 47.48$ & 22 & 4.98 & \begin{tabular}{|l|l|}
53 & 11.88 \\
\end{tabular} & \begin{tabular}{|l|l|}
81 & $18.0 \times$ \\
\end{tabular} & & $13.6 \mathrm{x}$ & 19 & $4.2 x$ & 449 & 100.08 \\
\hline \multirow{4}{*}{ 周山晨 } & 夫妈酸在 & $97 \mid 34.3 \times]$ & 23 & 8.15 & $34 \sqrt[12.08]{ }$ & 8229.08 & & 14.18 & 7 & $2.5 x$ & 283 & $100.0 x$ \\
\hline & 夫のみ & $\begin{array}{ll}715.68 \\
\end{array}$ & 4 & 8.98 & \begin{tabular}{|l|l|}
4 & $8.9 x$ \\
\end{tabular} & \begin{tabular}{|l|l|l|l}
20 & $44.4 x$ \\
\end{tabular} & & $22.2 x$ & 0 & $0.0 \times$ & 45 & $100.0 x$ \\
\hline & 㡠のみ & $23|16.8 x|$ & 6 & $4.4 x$ & \begin{tabular}{l|l|l|}
15 & 10.98 \\
\end{tabular} & 5439.48 & & 27.08 & 2 & $1.5 x$ & 137 & $100.0 \%$ \\
\hline & Bt & 12727.38 & 33 & 7.18 & \begin{tabular}{|l|l|}
53 & $11.4 x$ \\
\end{tabular} & \begin{tabular}{|l|l|}
156 & 33.58 \\
\end{tabular} & & $18.7 x$ & & 1.96 & 465 & $100.0 x$ \\
\hline \multirow{4}{*}{ 丕川景 } & 夫螎星在 & $\begin{array}{l}45 \mid 29.6 x \\
\end{array}$ & & 17.88 & $3724.3 x$ & \begin{tabular}{|l|l|}
25 & $16.4 x$ \\
\end{tabular} & & $10.5 x$ & 2 & $1.3 \mathrm{x}$ & 152 & 100.08 \\
\hline & 夫のみ & $1442.4 x$ & 41 & 12.18 & $\begin{array}{l}5 \mid 15.2 x \\
\end{array}$ & \begin{tabular}{l|l|l|}
3 & 9.18 \\
\end{tabular} & & $18.2 x$ & 1 & $3.0 x$ & 33 & $.100 .0 x$ \\
\hline & 監のみ & $48(49.0 x$ & 7 & 7.18 & $12|12.2 x|$ & $14 \mid 14.35$ & & 16.38 & & 1.08 & 98 & 100.08 \\
\hline & 时 & $10737.8 x$ & & 13.48 & \begin{tabular}{|l|l|}
54 & 19.18 \\
\end{tabular} & $42 \mid 14.8 x$ & & 13.48 & 4 & $1.4 \times$ & 283 & $100.0 \%$ \\
\hline \multirow{4}{*}{ 高知军 } & 夫绍跑在 & $51 \mid 21.7 x$ & & $18.3 x$ & $48 \mid 20.4 \times$ & \begin{tabular}{l|l|l|l|l|}
63 & 26.88 \\
\end{tabular} & & $8.9 x$ & 9) & 3.88 & 235 & $100.0 x$ \\
\hline & 夫のみ & 18.42 .95 & & 14.35 & 5 & $921.4 \times$ & & 7.18 & 1 & $2.4 x$ & 42 & 100.08 \\
\hline & 暒のみ & \begin{tabular}{ll|l|l|}
$433.65 x$ \\
\end{tabular} & & $17.2 \times$ & \begin{tabular}{|l|l|}
$16.5 x$ \\
\end{tabular} & 3124.28 & & $10.2 \times$ & 3 & 2.3 .3 & 128 & 100.08 \\
\hline & at & 11227.78 & & 17.58 & \begin{tabular}{l|l}
69 & $17.0 \times$ \\
\end{tabular} & 10325.48 & 37 & 9.18 & 13. & $3.2 \mathrm{x}$ & 405 & $100.0 \%$ \\
\hline \multirow{4}{*}{ 梄岡泉 } & 夫姆微在 & 15750.68 & 15. & $4.8 x$ & \begin{tabular}{l|l|}
20 & $6.5 x$ \\
\end{tabular} & $80 \mid 25.88 x$ & 28 & $9.0 x$ & 10 & 3.28 & 310 & $100.0 x$ \\
\hline & 夫のみ & $3754.4 x$ & 2 & 2.98 & $811.8 x$ & $1826.5 x$ & & $1.5 x$ & 4 & 2.98 & 68 & $100.0 \times$ \\
\hline & 逐のみ & $85 \mid 48.08\}$ & 6 & 3.48 & 2011.38 & \begin{tabular}{|l|l|}
48.18 \\
\end{tabular} & 14. & 7.95 & 4 & $2.3 x$ & 177 & 100.05 \\
\hline & 财 & $279 \mid 50.3 \times$ & 23 & 4.18s & \begin{tabular}{|l|l|}
48 & 8.68 \\
\end{tabular} & $146|26.38|$ & & 7.78 & 16 & 2.94 & 555 & $100.0 \%$ \\
\hline \multirow{4}{*}{ 昨本只 } & 夫妱姐在 & $-54 / 27.38$ & 11 & 5.68 & $42|21.2 x|$ & $7035.4 x$ & & $10.6 x$ & of & $0.0 x$ & 198 & 100.05 \\
\hline & 夫のみ & \begin{tabular}{l|l|l|}
3 & 7.58 \\
\end{tabular} & 2 & 5.08 & $922.5 x$ & $2050.0 \times$ & & $15.0 x$ & of & $0.0 x$ & -40 & $100.0 x$ \\
\hline & 进のみ & \begin{tabular}{l|l|}
22 & $17.2 x$ \\
\end{tabular} & 6 & 4.78 & \begin{tabular}{|l|l|}
$248.8 x$ \\
\end{tabular} & $57 \mid 44.58$ & & 14.8x] & 0 & 0.08 & 128 & 100.08 \\
\hline & Bt & $79|21.68|$ & 19) & $5.2 x$ & $75 \mid 20.5 x$ & $147 / 40.28$ & & $12.6 x$ & ol & 0.08 & 366 & $100.0 x$ \\
\hline & 合斯 & $917|36.3 x|$ & 206 & $8.2 x$ & \begin{tabular}{l|l|}
352 & $14.0 x$ \\
\end{tabular} & $675 \mid 26.8 \times$ & & $12.4 x$ & 611 & $2.4 x$ & 2523 & $100.0 \%$ \\
\hline
\end{tabular}

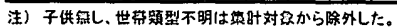
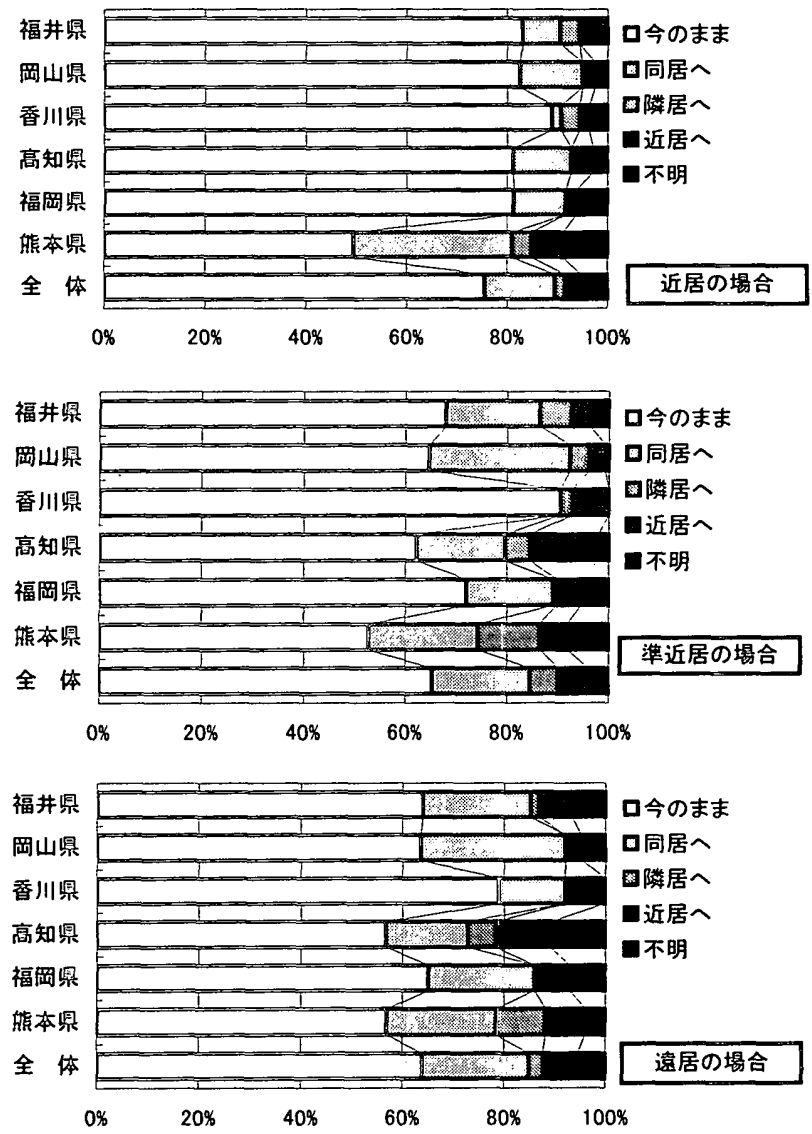

图4 希望する将来のサポート居住類型

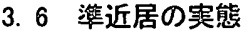

以上のように、幾つかのサポート居住類型の中で「準近居」の占 める比率が多いことが判明した。

図 5 は、各県において発生している「準近居」の典型的な事例を 抽出し、出身地、居住地、就業地の位置関係を示したものである。 これにより、親元（出身地）と県内中心都市の中間地に居を構え、 一方で親世帯への配慮を担保しつつ、他方で自らの就業の便を考慮 した「準近居」の様相を明瞭に認識することができよう。 


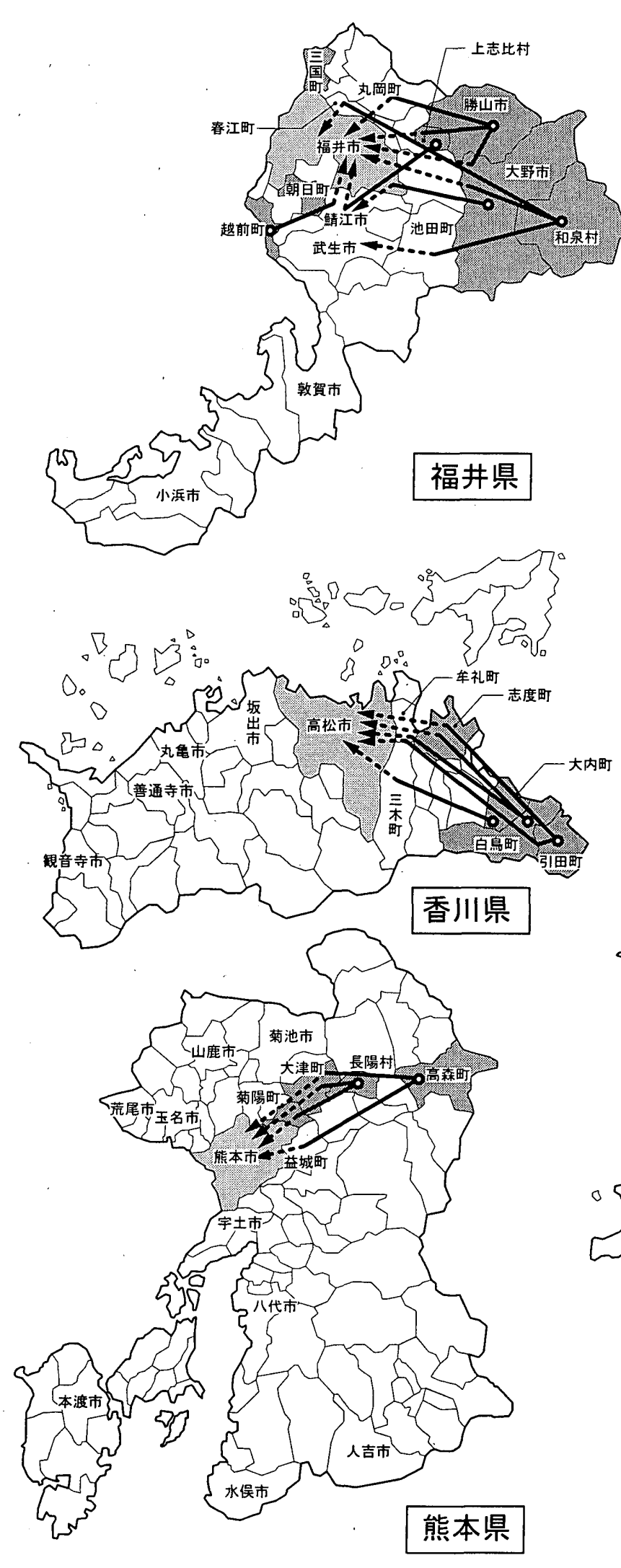

熊本県
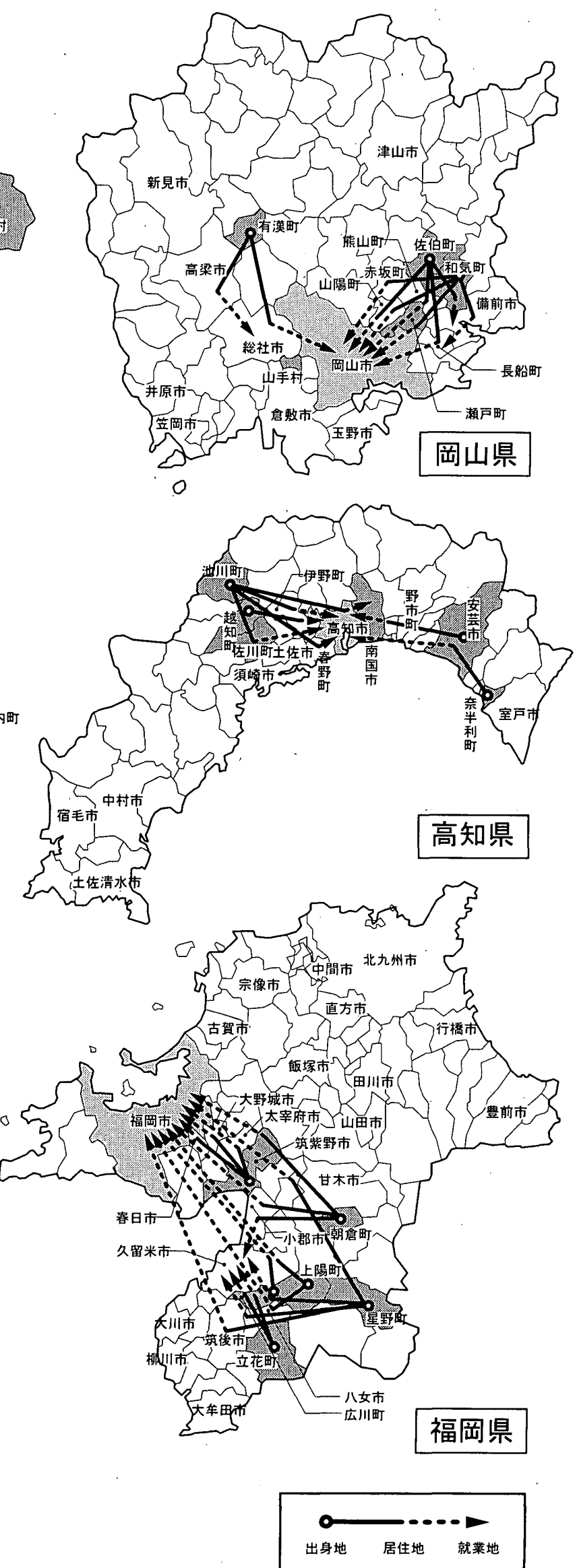

図5準近居の発生事例における出身地·居住地·就業地の位置関係 


\section{4. まとめ}

以上の考察の結果、下記の諸点が明らかになった。

(1) 親子両世帯間の居住関倸は、東日本を中心として依然として同 居の占有率が高いものの、その減少傾向は著しく、同居以外の居住 関倸が増加の傾向にある。

(2) 同居以外では、準近居の増加が顕著であり、市町村によっては 同居を大幅に上回るケースも少なくなく、今後、親子の居住関係に おける主軸として進展する可能性が高い。

(3) 潐近居の発生比率は、県内中心都市からみて遠隔地になるほど 高くなる傾向がみられる。また、子世帯が準近居を選択するにあた っては親世帯に対するケアを念頭においていることが確認された。 これらの事実により、子世帯が親世帯へのケアと自らの就業の便の 両者を満たすべく、親元と就業地との中間地に居を構えると定義し た準近居の仮説は実証されたと考えられる。

(4) 親世帯は、子世帯とつかず離れずの居住関係を概ね肯定してお り、準近居の増加傾向と重ね合わせると、親世帯は自立と依存・支 嗳のバランスがとれた居住環境を求めていることが示唆される。

(5)このような意味でも、準近居における生活実態は、今後の親子 両世帯間および近隣を含めたサポートネットワークの構築にあたっ て示唆的な情報が得られる可能性がある。この点は次編の分析課題 としたい。

（6）また、準近居の存在は、各市町村単位を越えた広域において住 宅政策および高齢者施策等を講じる必要を示唆している。

\section{謝辞}

調査の実施にあたり福山市立女子短期大学助教授・正保正恵氏な らびに各市町村の民生委員、福祉課長、住民課長の方々に多大なご 支援を賜った。ここに記して感謝の意を表します。また、本研究は、 財団法人・住宅総合研究財団より 2000 年度研究助成を受けておこな ったものである。ここに記して感謝の意を表します。

\section{引用文献}

1）那須宗一 : 現代社会と老人の家族移動，那須宗一・増田光吉編老人と家族の 社会学所収, 垣内出版, 1972

2）高阪謙次 : 高齢者の同別居の現状と志向に関する研究，特に「親密別居」の 動向を通して，日本建築学会計画系諭文報告集，第 409 号，pp 85-94，1990.3

3）広原盛明 : 住宅の近未来像，21世紀はどこでだれと住むか, 都市住宅学, 第 26 号, pp 52-61, 1999

4）松永有介 : 変容する相互扶助機能「家族 から「家族ネットワーク」へ，「ライフプ ラン新時代変わる社会・広がる選択 所収, 野村総合研究所, pp 80-135, 1997

5）総理府広報室編：月刊世論調查・平成 5 年 3 月号, 平成 6 年 3 月号, pp34-37, 大藏省印刷局, 1994

6）直井道子 : 高龄者と家族，新しいつながりを求めて，サ仜ンス社，1993

7）総務庁編：高齢社会白書，大藏省印刷局，2000

\section{参考文献}

1）清水浩昭 : 高齢化社会と家族構造の地域性人口変動と文化伝統をめぐって, 時潮社, 1992

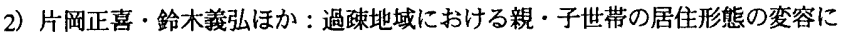
関する研究, 日本建築学会研究報告 (九州支部), 第 34 号・3，1994.3

3）金貞均，近江隆 : 現代家族の分散居住の実態と居住ネットワークの形成，日 本建築学会計画系諭文集，第 456 号, pp 209-216, 1994.2

4）清水浩昭 : 家族は変わったのか，住宅金融月報平成 6 年 7 月号, pp 4-9

5）山田英代·玉置伸俉 : 高秢者を含む世帯の家族構造の変化に関する統計分析, 日本建築学会計画系論文集, 第 483 号, pp 199-210, 1996.5

6 牛山美緒 : 家族像の変化と今後の住宅需要に関する研究 (その 2), 住宅都 市整備公団調查研究期報, No.110,pp 27-46, 1996 年

7）青本正夫, 糸乗貞喜, 上和田茂ほか : 高齡者はなぜふるさとを離れたのか, 総合研究開発機構研究報告書, 第 960079 号, 1996

8）森岡清美・望月禽：『新しい家族・四訂版』，培風館，1997

9）本村汎：住居が提供される主体としての修正直系昖大家族，『家族と住居の相互性 をめぐって』所収, 都市住宅学会関西支部・家族と住居研究小委員会, 1997

10）大森敏江 : 小子化時代のファミリ一世帯と二世帯住宅，『家族と住居の相互 性を巡って』所収, 都市住宅学会関西支部・家族と住居研究小委員会, 1997

11）藤崎宏子：高龄者・家族・社会的ネットワーク，培風館，1998

12）安達正瞦 : 高齢期家族の社会学, 世界思想社, 1999

13）上和田茂：三世帯同居の持続性と変容, 広原盛明·岩崎信彦·高田光雄編著『少 子貴龄時代の都市住宅学乺収, ミネルヴァ書房, 2002 